\title{
Rhizome Extract of White Ginger (Zingiber officinale Roxb) Maintains Testicular Function of Aging Mice
}

\author{
Sutyarso $^{1}$, Hendri Busman ${ }^{1}$, Mohammad Kanedi ${ }^{1, ~ *}$, Muhartono ${ }^{2}$ \\ ${ }^{1}$ Department of Biology, Faculty of Mathematics and Natural Sciences University of Lampung, Bandar Lampung, Indonesia \\ ${ }^{2}$ Department of Anatomical Pathology, Faculty of Medicine, University of Lampung, Bandar Lampung, Indonesia
}

Email address:

wegayendi@yahoo.com (M. Kanedi)

${ }^{*}$ Corresponding author

\section{To cite this article:}

Sutyarso, Hendri Busman, Mohammad Kanedi, Muhartono. Rhizome Extract of White Ginger (Zingiber officinale Roxb) Maintains Testicular Function of Aging Mice. International Journal of Nutrition and Food Sciences. Vol. 5, No. 3, 2016, pp. 175-178. doi: $10.11648 /$ j.ijnfs.20160503.14

Received: March 27, 2016; Accepted: April 5, 2016; Published: April 26, 2016

\begin{abstract}
Ginger is recognized as antioxidants and chemoprotective. Therefore the rhizome extract of this plant could allegedly reverse aging process. The study is intended to investigate the possible effects of rhizome extract of white ginger (Zingiber officinale Roxb.) on the testicular function of aging male mice (Mus musculus Linn.). Male albino mice aged 12-14 months, grouped into three consisted of 12 mice, were given extract orally as follows: $0 \mathrm{mg} / \mathrm{kg}$ (as a control), 50mg $/ \mathrm{kg}$ and 100 $\mathrm{mg} / \mathrm{kg}$ daily for 70 days. The testicular function parameters assessed were: the number of spermatogenic cells, the number and quality of sperm. Compared to control group, male mice treated with ginger extract showed significant high quality of sperm count, viability, motility and morphology $(\mathrm{P}<0.001)$. Histological parameters of the testis: pre-leptotene as well as pachytene spermatocytes and spermatids cells also significantly higher in the treated group $(\mathrm{P}<0.01)$ than that of control. In conclusion, rhizome extract of ginger effectively maintain function of reproductive system of male mice in aging process and, thus, ginger is potentially as the fertility and anti-aging herbs.
\end{abstract}

Keywords: Ginger, Testicular Function, Anti-aging, Antioxidants

\section{Introduction}

Aging process is occurred naturally and must be experienced by all living organisms. Aging is a complex changes related to the age of the organism causing an increased probability of death. It might include regular changes in genetic, biochemical, morphological, and physiological process. In short, the aging process occurs in every organ system, including the reproductive system characterized by declining fertility. However, factors that can prevent or promote the aging process in the male reproductive system are largely unknown $[1,2]$.

In male subjects, spermatogenesis is normally regulated appropriately to keep the continuous cell proliferation and the programmed cell death, known as apoptosis, is in balance [3]. Germ cell death may be increased by various causes, such as testicular injury, exposure to toxins, exposure to heat, radiation, hormonal imbalance, chemotherapy and free radicals $[4,5,6]$. On the one hand there are still many aspects of aging are not yet known, but on the other hand there is a lot of evidence to suggest that age-related diseases can be prevented or treated with plant-derived ingredients, mainly the ingredient containing free-radical scavengers (antioxidant) such as vitamin E, ascorbic acid, glutathione, carotenoid, and flavonoids [7]. One of the medicinal plants which is very popular among modern societies is ginger (Zingiber officinale) [8].

Extracts of ginger plant has recently proven to play variety of biological roles, including anticancer, antioxidant, antiinflammatory and antimicrobial [9]. In adult male rats ginger is known to have hypocholesterolemic effect and lead to weight loss, decrease blood glucose, serum total cholesterol and serum alkaline phosphatase [10]. A recent study suggested that ginger extract can improve histological damage and reduce apoptosis of testicular cells in mice induced with metiram-fungicide [11]. This may be due to the 
antioxidant properties of the ginger extract $[12,13]$.

Although ginger has been widely used and studied in the biomedical field but reports on the effects of this plant extract on the aging process, especially in testicular function, still very limited. However, given the ginger extract is an antioxidant and chemo-protective, it is very likely that this Zingiberaceous plants can be used as anti-aging herbs.

\section{Materials and Methods}

\subsection{Herbs Materials and Extraction}

The rhizomes of white ginger (Zingiber officinale Roxb) used in this study was obtained from ginger farmers in Gisting, the District of Tanggamus, Lampung Province, Indonesia. Fresh rhizomes were washed thoroughly in distilled water to remove contaminants, chopped into small pieces, and sun-dried between 10:00 to 12:00 o'clock. The small pieces of the dried rhizomes milled into powder form. The powder macerated in distiled water for 48 hour at room temperature. Macerates filtered and evaporated at $40-50^{\circ} \mathrm{C}$ until light brown semisolid extract formed. Before further use the extracts were stored in air-tight container in refrigerator.

\subsection{Experimental Animal and Treatment}

Thirty six male Swiss albino mice, aged 12 - 14 months, obtained from Lampung Veterinary Center, Indonesia, were used as experimental animals. The use of mice of such age is based on a research report stating that the mice at the age of 6 months are already showing signs of aging [14]. By using a completely randomized design, the experimental animals designated into 3 groups consisted of 12 each. The first group was given aquades orally as the control group. The second group received $50 \mathrm{mg} / \mathrm{kg}$ of rhizome extract, while the third group received $100 \mathrm{mg} / \mathrm{kg}$ of the extract. The treatment was carried out once daily for 70 days, during which both pellet and water available ad libitum.

\subsection{Surgical Procedures}

Before treatment and towards sacrifice, the mice weighed. The animals were sacrificed after deeply anesthetized by ether 24 hours after the last dose is given. Testis and epididymis is taken by dissecting the peritoneal cavity at the posterior part of the abdomen. Any excess fat or connective tissue removed from the sampled organs, and then both testis and epididymis weighed using analytical-density digital balance with readability of $0.0001 \mathrm{~g}$.

\subsection{Sperm and Testicular Examination}

Imediately after weghing, semen in the epididymis squeezed and diluted with physiological saline. Spermatozoa was counted using a Neubauer haemocytometer under a light microscope at $400 \mathrm{x}$ magnification and expressed as million/ml of suspension. Quantitative epididymal sperm motility expressed as an index determined by counting both motile and immotile spermatozoa per unit area. Sperm viability examined using supravital staining made by adding $10 \mu \mathrm{L}$ of eosin-Y $0,5 \%$ into the $10 \mu \mathrm{L}$ of semen suspension. Sperm morphology was assessed from a epididymis filtrate smeared on a clean glass slides by addition of a drop of $1 \%$ eosin. Once the object dried, observation done under a light microscope at $400 \mathrm{x}$ magnification and the abnormalities of either head or tail were noted.

To assess the seminiferous tubular diameters, the spermatocyte and spermatid cell counts, left testis from each mouse was fixed in Bouin's solution. The organs were cut at the thickness $5 \mu \mathrm{m}$ and stained with hematoxylin and eosin and examined under a light microscope. The diameter of tubulus seminiferus was determined by measuring the width of the tubules using occulometer. Spermatocyte and spermatid cells were counted from 10 seminiferous tubule and then averaged.

\subsection{Statistical Analysis}

The data, presented as Mean \pm SEM, was analysed with a one-way ANOVA. Means were separated using Least Significance Difference (LSD) test. All of the statistics that applied are programmed in SPSS version 21.

\section{Results and Discussion}

Body weight, testis and epididymis weight of mice treated with and without rhizome extracts of ginger (Zingiber officinale Roxb.) are presented in Table 1. Of the four parameters only final body weight shows a significant difference between control and treated mice $(p<0.05)$.

Table 1. Body weight, testis and epididimis weight of mice treated with and without rhizome extracts of white ginger (Zingiber officinale Roxb.)

\begin{tabular}{lllll}
\hline Parameters & Mice without ginger & Mice given ginger 50 mg/kg & Mice given ginger 100mg/kg & ANOVA (p-value) \\
\hline Initial body weight $(\mathrm{g})$ & $27.25 \pm 2.18^{\mathrm{a}}$ & $28.33 \pm 1.92^{\mathrm{a}}$ & $27.83 \pm 1.85^{\mathrm{a}}$ & 0.420 \\
Final body weight $(\mathrm{g})$ & $30.67 \pm 3.28^{\mathrm{a}}$ & $34.83 \pm 3.59^{\mathrm{b}}$ & $33.83 \pm 4.09^{\mathrm{b}}$ & 0.023 \\
Testicular weight $(\mathrm{mg})$ & $85.33 \pm 11.43^{\mathrm{a}}$ & $92.50 \pm 7.47^{\mathrm{a}}$ & $94.27 \pm 9.68^{\mathrm{a}}$ & 0.070 \\
Epididymis weight $(\mathrm{mg})$ & $18.31 \pm 3.47^{\mathrm{a}}$ & $20.52 \pm 3.81^{\mathrm{a}}$ & $20.90 \pm 3.30^{\mathrm{a}}$ & 0.168 \\
\hline
\end{tabular}

Values are mean \pm SE; values of each parameter that share the same superscript are not significantly different at $\alpha=0.05$ using LSD test

Table 2 presents the data of quantity as well as quality of sperm of mice receiving ginger extract in comparison to control. All sperm parameters of mice treated with ginger extracts significantly differ from that of control $(p<0.01)$. Ginger extracts increase sperm counts, viability and motility and maintain normal sperm morphology as well. 
Table 2. The number, viability, motility and morphology of sperm of mice treated with and without rhizome extracts of white ginger (Zingiber officinale Roxb.)

\begin{tabular}{lllll}
\hline Parameters & Mice without ginger & Mice given ginger 50mg/kg & Mice given ginger 100mg/kg & ANOVA (p-value) \\
\hline Sperm counts (x10 $/ \mathrm{ml})$ & $5.95 \pm 1.82^{\mathrm{a}}$ & $9.88 \pm 2.40^{\mathrm{b}}$ & $11.77 \pm 2.53^{\mathrm{c}}$ & 0.000 \\
Sperm viability (\%) & $47.98 \pm 7.35^{\mathrm{a}}$ & $58.34 \pm 9.06^{\mathrm{b}}$ & $60.36 \pm 5.71^{\mathrm{b}}$ & 0.001 \\
Sperm motility (\%) & $46.05 \pm 7.43^{\mathrm{a}}$ & $60.11 \pm 6.84^{\mathrm{b}}$ & $62.86 \pm 8.57^{\mathrm{b}}$ & 0.000 \\
Abnormal sperm (\%) & $15.31 \pm 3.46^{\mathrm{a}}$ & $9.27 \pm 2.01^{\mathrm{b}}$ & $10.85 \pm 3.28^{\mathrm{b}}$ & 0.000 \\
\hline
\end{tabular}

Values are mean $\pm \mathrm{SE}$; values of each parameter that share the same superscript are not significantly different at $\alpha=0.05$ using LSD test

The allegedly effects of ginger extracts on testicular histology parameters are presented in Table 3. Of the five parameters only spermatogonia number that show no difference between control and treated mice. Pre-leptotene as well as pachytene spermatocyte and spermatid counts are significantly higher in mice given ginger extract than that of control.

Table 3. Testicular histology parameters of mice treated with and without rhizome extracts of white ginger (Zingiber officinale Roxb).

\begin{tabular}{|c|c|c|c|c|}
\hline Parameters & Mice without ginger & Mice given ginger $50 \mathrm{mg} / \mathrm{kg}$ & Mice given ginger $100 \mathrm{mg} / \mathrm{kg}$ & ANOVA (p-value) \\
\hline Semiferus diameter $(\mu \mathrm{m})$ & $178.23 \pm 8.52^{\mathrm{a}}$ & $193.08 \pm 11.09^{b}$ & $192.16 \pm 11.65^{b}$ & 0.002 \\
\hline Spermatogonia counts & $2.14 \pm 0.11^{\mathrm{a}}$ & $2.27 \pm 0.31^{\mathrm{a}}$ & $2.13 \pm 0.11^{\mathrm{a}}$ & 0.177 \\
\hline Pre-leptotenespermatocyte counts & $7.49 \pm 1.95^{\mathrm{a}}$ & $12.28 \pm 4.05^{\mathrm{b}}$ & $14.51 \pm 3.66^{\mathrm{b}}$ & 0.000 \\
\hline Pachytene spermatocytecounts & $8.58 \pm 2.09^{\mathrm{a}}$ & $18.64 \pm 4.08^{\mathrm{b}}$ & $19.02 \pm 2.81^{\mathrm{b}}$ & 0.000 \\
\hline Spermatid counts & $23.78 \pm 3.92^{\mathrm{a}}$ & $56.69 \pm 12.97^{b}$ & $57.82 \pm 9.10^{\mathrm{b}}$ & 0.000 \\
\hline
\end{tabular}

Values are mean $\pm \mathrm{SE}$; values of each parameter that share the same superscript are not significantly different at $\alpha=0.05$ using LSD test

As has been revealed by previous studies, all testicular parameters such as used in this study, were decreased or lower in male mice that were in the process of aging $[14,15$, 16]. The findings of this study suggest that the administration of rhizome extracts of white ginger is potentially able to reverse the aging process of reproductive function in male mice by maintaining the high value of testicular parameters both quantitatively and qualitatively. Regardless of aging context, these results are consistent with the findings that ginger extract supplements in adult male mice improve the quality of reproductive and spermatogenesis parameters [17]. This promising result might strongly be related to the antioxidative and chemoprotective properties of the active ingredient in the rhizome extract of ginger.

Studies using animal models suggest that ginger is useful as antioxidant [18]. The testes of mice induced with an antibiotic gentamicin may undergo histological damage and poptosis in the spermatogenic cells, treatment with ginger extract was able to recover such damages [19]. The strong evidence that the ginger extract is an antioxidant has shown by the increased activity of oxidase enzyme SOD (superoxide dismutase) and catalase in rat testis induced by formalin [20]. Moreover, ginger is also found to have a protective effect against $\mathrm{H}_{2} \mathrm{O}_{2}$-induced DNA damage, and proven to improve the quality of sperm parameters in mice [21, 22].

In addition to antioxidative and chemoprotective properties, ginger is also androgenic, because it proved to stimulate the production of testosterone [23]. The most active ingredient and fundamental of ginger are gingerol and shogaol. These bioactives have shown a protective effect in diabetes related to abnormalities function of liver, kidney, eye and nervous system [24, 25]. In infertile men, treatment of ginger extract in addition to increasing testosterone levels also proven to significantly increase the levels of serum LH and FSH. Thus it can be assumed that ginger extract could maintains the function of hypothalamus-hypophysis-testis axis $[26,27]$. Thus the presumption that ginger extracts is pro-fertility as well as steroidogenic in male rats, is reasonable and acceptable [28].

The only findings of this study that looked like contrary to expectations and previous research is the weight of mice which is higher at the end of treatment (Table 1). On the one hand, mice that were in the process of aging should have a higher body weight with age [14]. On the other hand, in fact, ginger extract has great ability to reduce body weight without inhibiting pancreatic lipase level or affecting bilirubin concentration [29]. However, in this study the control and the experimental animal are both consisted of aging mice. Thus comparing both old mice as comparing the older mice to the younger ones are not appropriate.

Therefore, a reasonable explanation to this research gap is referring to research reported by [30] that in mice, body weight is influenced by sex hormones. The lower the sex hormone levels the higher the weight lost. Given the results of this study actually showed increased levels of sex hormones, characterized by high spermatogenic parameters, the high weight at the end of the treatment of old mice is something natural.

\section{Conclusion}

Rhizome extract of ginger effectively maintain function of 
reproductive system of male mice in aging process and, thus, ginger is potentially as fertility and anti-aging herbs.

\section{References}

[1] Wang C., Hikim A. P. S., Lue y., Leung A., Baravarian S. and Swerdloff R. S. (1999). Reproductive Aging in the Brown Norway Rat Is Characterized by Accelerated Germ Cell Apoptosis and Is Not Altered by Luteinizing Hormone Replacement. J Androl 20: 509-18.

[2] Zahidov S. T., Hohlov A. N., Malolina E. A., Yu-Kulibin A. and Marshak T. L. (2010). Ageing of the Spermatogenesis System. Biol. Bull. 37: 10-17.

[3] Sinha H. A. P., Rajavashisth T. B., Sinha H. I., Lue Y., Bonavera J., Leung A., Wang C., Swerdloff R. S. (1997). Significance of apoptosis in the temporal and stage-specific loss of germ cells in the adult rat after gonadotropin deprivation. Biol. Reprod57: 1193-201.

[4] Meistrich M. L. (1993). Effects of chemotherapy and radiotherapy on spermatogenesis. Eur Urol23: 136-41

[5] Ames B. N., Shigenaga M. K., and Hagen T. M. (1993). Oxidants, antioxidants, and the degenerative diseases of aging: Review. Proc. Natl. Acad. Sci. USA. Vol. 90, pp. 7915-7922.

[6] Sies H. (1997). Oxidative stress: Oxidants and antioxidants. Experimental physiology 82 (2): 291-5.

[7] Hansakul P. (2010). Celullar Aging. Thammasat Medical Journal, Vol. 10 No. 3: 311-319.

[8] Mascolo N., Jain R., Tain S., and Capasso F. (1989). Ethnopharmacologic investigation of ginger (Zingiber officinale). J Ethno Pharmacol 27: 129-40.

[9] Kamtchouing P., Mbongue-Fandio G. Y., Dimo T. and Jatsa H. B. (2002). Evaluation of androgenic activity of Zingiber officinale extracts in male rats. Asian J Androl 4: 299-301.

[10] Bhandari U., Kanojia R. And Pillai K. K. (2005). Effect of ethanolic extract of Zingiber officinale on dyslipidaemia in diabetic rats. J Ethnopharm 97: 227-30.

[11] Sakr SA. Badawy GM. (2011). Effect of ginger (Zingiber officinale R.) on metiram-inhibited spermatogenesis and induced apoptosis in albino mice. J App Pharm Sci 2011; 1: 131-36.

[12] Morakinyo A. O., Adeniyi O. S. and Arikawe A. P. (2008). Effects of Zingiber officinale on reproductive functions in the male rat. African J Biomed Res 11: 329-34.

[13] Khaki A., Khaki A. A., Hajhosseini L., Golzar F. S. and Ainehchi N. (2014). The anti-oxidant effects of ginger and cinnamon on spermatogenesis dys-function of diabetes rats. African Tradit Comp Altern Med 11: 1-8.

[14] Takanao H. and Abe K. (1987). Age-Related Histologic Changes in the Adult Mouse Testis. Arch. Histol. Jap., Vol. 50, No. 5 (1987) p. 533-544.

[15] Hwang S. Y., Sohn S. H., Wee J. J., Yang J. B., Kyung J. S., Kwak Y. S., Kim S. W. and Kim S. K. (2010). Panax ginseng Improves Senile Testicular Function in Rats. J. Ginseng Res. Vol. 34, No. 4, 327-335.
[16] Chandrashekar V., Dawson C. R., Martin E. R., Rocha J. S., Bartke A. and Kopchick J. J. (2007). Age-Related Alterations in Pituitary and Testicular Functions in Long-Lived Growth Hormone Receptor Gene-Disrupted Mice. Endocrinology, 148(12): 6019-6025.

[17] Aleissa M. S. (2014). Effect of ginger supplements on some reproductive parameters and spermatogenesis of mice. Indian J Fund Appl Life Sci 4: 271-77.

[18] Hozayen W. G., Soliman H. A. and Abou-Seif H. S. (2014). Study of the chemopreventive effects of Zingiber officinale roots against aspartame induced testicular toxicity in rat model. J Phys Pharm Adv 4: 360-67.

[19] Zahedi A. And Khaki A. (2014). Recovery effect of Zingiber officinale on testis tissue after treatment with gentamicin in rats. J Med Plant Res 8: 288-91.

[20] Rasyidah T. I., Suhana S., Nur H. A., Kaswandi M. A. and Noah R. M. (2014). Evaluation of antioxidant activity of Zingiber officinale (ginger) on formalin-induced testicular toxicity in rats. J Med Bioeng 3: 149-53.

[21] Maheshwari A., Misro M. M., Aggarwal A., Sharma R. K. and Nadan D. (2011). N-Acetyl-L-cysteine counteracts oxidative stress and prevents $\mathrm{H}_{2} \mathrm{O}_{2}$ induced germ cell apoptosis through down-regulation of caspase- 9 and $\mathrm{JNK} / \mathrm{c}-\mathrm{jun}$. Moll Reprod Dev78: 69-79.

[22] Khaki A., Fathiazad F., Nouri M., Khaki A. And Chelar C. O., Marefat N. And Hamadeh M. (2009). The Effects of Ginger on Spermatogenesis and Sperm parameters of Rat. Iranian J Reprod Med 7: 7-12.

[23] Hafez D. A. (2010). Effect of extracts of ginger goots and cinnamon bark on fertility of male diabetic rats. J Am Sci 6: 940-47.

[24] Sekiwa Y., Kubota K. and Kobayashi A. (2008). Isolation of novel glycosides from ginger and their atioxidative activity. J Agri Food Chem 8: 373-79.

[25] Khaki A., Khaki A. A., Hajhosseini L., Golzar F. S. and Ainehchi N. (2014). The anti-oxidant effects of ginger and cinnamon on spermatogenesis dysfunction of diabetes rats. AfricanTradit Comp Altern Med 11: 1-8.

[26] Mares W. A. A. K. and Najam W. S. (2012). The effect of ginger on semen parameters and serum FSH. LH \& testosterone of infertile men. Tikrit Medical J 18: 322-29.

[27] Morakinyo A. O., Achema P. U. and Adegoke O. A. (2010). Effect of Zingiber officinale (Ginger) on sodium arsenitinduced reproductive toxicity in male rats. African J Biomed Res 13: 39-45.

[28] Morakinyo A. O., Oludare G. O., Aderinto O. T. and Tasdup A. (2011). Antioxidant and free radical scavenging activities of aqueous and ethanol extracts of Zingiber officinale. Biol Med 3: 25-30.

[29] Mahmoud R. H. and Elnour W. A. (2013). Comparative evaluation of the efficacy of ginger and orlistat on obesity management, pancreatic lipase and liver peroxisomal catalase enzyme in male albino rats. Eur Rev Med Pharmacol Sci 17 (1): 75-83.

[30] Ghorbani R., Mokhtari T., Khazaei M., Salahshoor M. R., Jalili C. and Bakhtiari M. (2014). The effect of walnut on the weight, blood glucose and sex hormones of diabetic male rats. Int. J. Morphol. 32(3): 833-838. 